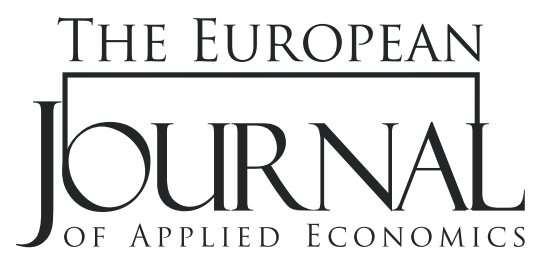

EJAE 2019, 16(1): 1-19

ISSN 2406-2588

UDK: $331.101 .6(611)$

331.445:159.922.6

DOI: 10.5937/EJAE15-18209

Original paper/Originalni naučni rad

\title{
POPULATION AGE STRUCTURE CHANGE AND LABOUR PRODUCTIVITY: EVIDENCE FROM TUNISIA
}

\author{
Olfa Frini*, Khoutem Ben Jedidia \\ University of Manouba, \\ Manouba, Tunisia
}

\begin{abstract}
:
Relying on a macroeconomic view, this paper investigated the population ageing effect on the aggregate labour productivity. It examined the effects of the labour force participation rate through three broad age ranges: young adulthood (15-29), prime age (30-49) and old age (5064). It computed the labour force participation rate by age considering the working-age of the same age range. Using Tunisian data covering the years 1965-2014, the cointegration method testified for a long-run relationship with a progressive adjustment process towards equilibrium. Unlike the conventional approach outcome, the age-productivity profile in our study did not follow an inverted U-shape. Labour productivity edged down for young workers, rose for the prime age adults, and kept on rising for older people. Accordingly, population ageing did not alter the Tunisian labour market performance. Thus, to achieve better productivity gains and enhance the country's economic growth, delaying the retirement age beyond 60 was advocated.
\end{abstract}

\section{Article info:}

Received: July 11, 2018

Correction: September 19, 2018

Accepted: November 19, 2018

\section{Keywords:}

population age structure change, labour force participation rate, labour productivity, error correction model, Tunisia.

\section{INTRODUCTION}

Population ageing may be dramatic for the economy affecting the labour market features through the slowdown of labour force population growth, and eventually causing its contraction (Cadiou et al., 2002; Peng, 2006; Bloom \& Sousa-Poza, 2013). The population ageing process influences the structure and performance of the labour market in two ways: (1) directly-via the supply and demand of labour and productivity, and (2) indirectly-via shifting the aggregate demand structure towards more services and products for the elderly. Labour force ageing might influence workers' mobility, employment, productivity and, consequently, labour market performance and flexibility. Thus, it is understood that the age-productivity profile is relevant for an ageing society. Several studies have focused on how the 
individual's productivity changes with age to reveal an inverted U-shaped profile as the aged are less productive than the young (Haltivanger et al., 1999; Crépon et al., 2002). However, these individual effects cannot be automatically assumed to apply collectively (Lindh \& Malmberg, 1999; Chawla et al., 2007; Brunow \& Hirte, 2006, 2008; Van Ours \& Stoeldraijer, 2010). It is difficult to systematically conclude, at a macroeconomic level, that an ageing population may lower the aggregate productivity and economic growth. Therefore, reviewing how the aggregate labour productivity changes with age also remains an important hot issue.

Within this framework, this paper investigated the population ageing effects on the labour market productivity from a macroeconomic perspective. To this end, and unlike previous studies which concentrated either on the total population (e.g. Barro \& Sala-i-Martin, 1992 and Lindh \& Malmberg, 1999), or on the working-age population (Mankiw, Romer \& Weil, 1992) or also on the employees (Brunow \& Hirte, 2006), we focused our empirical study on the labour force population. However, similar to Frini and Ben Jedidia (2018), we assessed the labour force according to the age structure effect, taking into account three age ranges: young adulthood (15-29 years), prime age (30-49), and old age (50-64). Nevertheless, our novelty lies in the fact that we estimated the labour force participation rate by age, defining it as a share of the labour force in the working-age population of the same age range.

Additionally, in order to predict the outcomes of the intended policy of postponing the retirement age, we extended it to 65 years, instead of 60 . This issue has been weakly addressed in the context of Arab countries before. However, we limited our study to the Tunisian case for the years 1965-2014, as it's well-advanced in population ageing.

To check the labour age-productivity profile, we applied the time series modelling approach using the cointegration technique to find out about the long-run equilibrium relationship between the variables and the Error Correction Model, in order to capture the short-run adjustment mechanism. Our methodology is rather standard, but is extensively used in macroeconomic analysis to check a dynamic long-run relationship.

The remainder of the paper was organized as follows: Section 2 developed a literature review. Section 3 depicted an overview of the demographic change and its consequences on the labour force age structure. Section 4 specified the applied model for our estimations. Section 5 detailed the econometric methodology and discussed the results before concluding and suggesting some policy recommendations in Section 6.

\section{LITERATURE REVIEW}

Demographic change modifies the population age distribution, the size of different age ranges of the working-age population, and, consequently, the labour force age structure which, in the long-run, may influence aggregate and age group-specific labour productivity (Dixon, 2003; Börsch-Supan, 2003; and Vodopivec \& Arunatilake, 2008). There are microeconomic and macroeconomic effects of ageing on labour productivity. However, to deal with some central macroeconomic issues about an ageing labour force productivity, our major concern in this paper requires a good understanding at the microeconomic level.

At this level, several studies, some of which are quoted in the table below, have displayed an inverted U-shaped age productivity profile; rising as workers enter prime age, and then declining as they approach retirement. 


\begin{tabular}{lccl}
\hline \multicolumn{1}{c}{ Author } & $\begin{array}{c}\text { Region/Country } \\
\text { and Period }\end{array}$ & $\begin{array}{c}\text { Productivity } \\
\text { Indicator }\end{array}$ & \multicolumn{1}{c}{$\begin{array}{c}\text { Age Productivity } \\
\text { Profile }\end{array}$} \\
\hline $\begin{array}{l}\text { Aubert and Crépon } \\
(2004)\end{array}$ & $\begin{array}{c}\text { France } \\
1994-2000\end{array}$ & Firm's value added & $\begin{array}{l}\text { Productivity increases with age in } \\
\text { the first part of working life, remains } \\
\text { stable around 40-45 or uncertain } \\
\text { thereafter. }\end{array}$ \\
\hline $\begin{array}{l}\text { Bruno and Hirte } \\
(2006)\end{array}$ & German & The regional & $\begin{array}{l}\text { The most promoting age group for } \\
\text { growth is 45-55; those over 55 years } \\
\text { reduce it. }\end{array}$ \\
\hline $\begin{array}{l}\text { Crépon } \text { et al. } \\
(2002)\end{array}$ & value-added & Firm's output & $\begin{array}{l}\text { Productivity peaks at 25-34, and de- } \\
\text { creases for those aged over 50. }\end{array}$ \\
\hline $\begin{array}{l}\text { Haltiwanger } \text { et al. } \\
(1999)\end{array}$ & Maryland US & Sales per employee & $\begin{array}{l}\text { Productivity increases until 55, and } \\
\text { decreases slightly after. }\end{array}$ \\
\hline $\begin{array}{l}\text { Ilmakunnas and } \\
\text { Maliranta }(2004)\end{array}$ & $\begin{array}{c}\text { Finland } \\
1995-2003\end{array}$ & Firm's value added & $\begin{array}{l}\text { Productivity peaks at around 40, and } \\
\text { decreases for those older. }\end{array}$ \\
\hline $\begin{array}{l}\text { Prskawetz } \text { et al. } \\
(2007)\end{array}$ & Austria & Firm's value added & Productivity peaks 30-49. \\
\hline
\end{tabular}

Table 1. An Empirical Overview of Age-Productivity in an Inverted U-Shape.

This negative ageing impact may be explained by the introduction and swift development of the new technologies (Bös \& Weizsäcker, 1989). Older workers have difficulties adjusting to new ways of working, which in return hampers their productivity. Additionally, they suffer from an ageing knowledge stock, skill obsolescence (De Grip \& Vanloo, 2002), declining cognitive abilities (notably by the age of 50, as stressed by Verbaegen and Salthouse (1997), and qualifications depreciation. This age-related reduction in cognitive abilities is an important cause of the age-related productivity decline (Skirbekk, 2003).

Moreover, the financial spurs to acquire new skills decline gradually with age, which lowers productivity. The recent study of Rožman et al. (2016) comparing older and younger employees in Slovenian companies concludes that older workers are less productive, less motivated, and less innovative and energetic. Moreover, the increase of health and infirmity incidences undermines labour productivity (Tanner, 1997). In contrast, young workers demonstrate a better ability for learning new skills, and a greater adaptability to new jobs.

This inverted U-shaped age-productivity profile is, however, not irrefutable and incontestable. Positive correlations between older workers and productivity were reached according to several studies (table 2 below). As argued by both Disney (1996) and Dixon (2003), older workers may have a higher average level of work experience, and a positive effect on productivity. They were consistently rated as having more positive attitudes, being more reliable, and possessing better skills than average workers. For instance, learning stimulates productivity as related to seniority (Aubert \& Crépon, 2003). Furthermore, older workers tend to have stable relationships with their employers, while young workers tend to frequently change jobs and employers (Gregg \&Wadsworth, 1999). The decline in voluntary job mobility may reduce the turnover costs for employers, including recruitment and initial training costs, which would have a favourable impact on overhead labour costs and profitability (Dixon, 2003). In addition, the older workers' contribution to firm-level productivity exceeds their contribution to the wage bill, as revealed by Cardoso et al. (2011). 


\begin{tabular}{|c|c|c|c|}
\hline Author & $\begin{array}{l}\text { Region/Country } \\
\quad \text { and Period }\end{array}$ & $\begin{array}{l}\text { Productivity } \\
\text { Indicator }\end{array}$ & $\begin{array}{l}\text { Age Productivity } \\
\text { Profile }\end{array}$ \\
\hline $\begin{array}{l}\text { Cardoso et al. } \\
\text { (2011) }\end{array}$ & $\begin{array}{l}\text { Portugal longitudinal } \\
\text { employer-employee } \\
\text { data } 1986-2008\end{array}$ & $\begin{array}{l}\text { Share of total number } \\
\text { of worker-hour }\end{array}$ & $\begin{array}{l}\text { Productivity increases until the age } \\
\text { range of 50-54 }\end{array}$ \\
\hline $\begin{array}{l}\text { Goebel \& Zwick } \\
\text { (2009) }\end{array}$ & $\begin{array}{l}\text { Germany employer- } \\
\text { employee data over } \\
\text { 1997-2005 }\end{array}$ & Marginal productivity & $\begin{array}{l}\text { Productivity increases until age } 55 \\
\text { and decreases slightly after that. }\end{array}$ \\
\hline $\begin{array}{l}\text { Malmberg et al. } \\
(2008)\end{array}$ & $\begin{array}{c}\text { Sweden } \\
1985-1996\end{array}$ & $\begin{array}{l}\text { Value added per } \\
\text { employee }\end{array}$ & $\begin{array}{l}\text { Older workers are more associated } \\
\text { with higher productivity than young- } \\
\text { er ones. }\end{array}$ \\
\hline $\begin{array}{l}\text { Mahlberg et al. } \\
(2013 \mathrm{~b})\end{array}$ & $\begin{array}{c}\text { Austria } \\
2002-2005\end{array}$ & $\begin{array}{l}\text { Average labour } \\
\text { productivity across } \\
\text { industrial sectors }\end{array}$ & $\begin{array}{l}\text { A positive correlation exists between } \\
\text { the share of older employees and } \\
\text { productivity, but no evidence for a } \\
\text { significant relationship between the } \\
\text { share of younger employees and pro- } \\
\text { ductivity was found. }\end{array}$ \\
\hline $\begin{array}{l}\text { Van Ours \& } \\
\text { Stoeldraijer (2010) }\end{array}$ & $\begin{array}{l}\text { Netherlands } \\
2000-2005\end{array}$ & Firm's value added & Increasing productivity up to age 57. \\
\hline
\end{tabular}

Table 2. An Empirical Overview of Productive Older Workers

From the above brief review, we can deduce that there is no agreement about the ageing-productivity nexus as related to the diversity of the required skills and individuals' capacities. In fact, this relationship depends on the nature of the work, education level, and physical demands. An age productivity profile is not necessarily static, but depends on labour market requirements, as suggested by Skirbekk (2008). Diminishing labour productivity at older ages seems to be particularly strong for work tasks where physical abilities, learning, and the speed of carrying out tasks are needed. Nevertheless, for jobs where experience and verbal abilities are important, older workers maintain a relatively high productivity level.

On the other hand, the empirical literature suggests that there might be differences in the ageproductivity profiles between/among sectors. For example, Aubert and Crépon (2006) conclude that relative productivity increases until the age of 35 for French manufacturing, trading, and services sectors. In trade, however, workers 40 to 59 are significantly more productive, and those between 45 and 54 are more productive than younger workers in services. Nevertheless, the authors showed that there are no differences in manufacturing between older workers and the 35-39 group. Van Ours and Stoeldraijer (2010) show significant differences in the age productivity patterns between sectors in the Netherlands. However, Mahlberg's and Prskawetz (2013b) study, dealing with mining, manufacturing, and market-oriented services sectors in Austria, proves a positive correlation between the older employees and productivity, but not a significant relationship with the younger ones.

Therefore, taking into account the fact that an ageing labour force differently influences productivity according to sectors, the total impact of ageing will depend on the industrial structure of an economy (Göbel \& Zwick, 2012). Accordingly, it is hard to systematically conclude at a macroeconomic level that ageing working population may lower the aggregate productivity and, consequently, the country's economic growth.

At the macroeconomic level, the ageing population effect is to reduce the relative size of labour force as a share of the total population. From this viewpoint, labour becomes relatively scarce, while capital becomes relatively more abundant. This engenders changes in the relative price of labour, and leads to a higher capital intensity. This labour force change affects economic growth. In details, as per 
capita output $\left(\frac{Y}{N}\right)$ (where $\mathrm{Y}$ denotes the output and $\mathrm{N}$ is the total population) is a function of capital (K), labour (L) and total factor productivity (A) as follows $\left(\frac{Y}{N}\right)=A f\left(\frac{L}{N}, \frac{K}{L}, \frac{L}{N}\right)$; a change in total population (N) (in its size and structure) changes the labour (L) structure and subsequently affects growth output (Bloom \& Williamson, 1998). A decline in N induces an increase of both the labour force ratio $\left(\frac{L}{N}\right)$ and capital intensity $\left(\frac{K}{L}\right)$. Moreover, considering the working-age population (WAP), this labour ratio $\left(\frac{L}{N}\right)$ can be expressed as a multiplication of two components $\left(\frac{L}{N}\right)=\left(\frac{L}{W A P}\right)\left(\frac{W A P}{N}\right)$ (Mankiw et al., 1992; Barro \& Sala-I-Martin, 1995). Henceforth, per capita output expression becomes a function of the labour force participation rate $\left(\frac{L}{W A P}\right) ;\left(\frac{Y}{N}=\frac{Y}{L}\left(\frac{L}{W A P}\right)\left(\frac{W A P}{N}\right)\right)$. This expression highlights the effects of the labour force participation rate, and therefore of its age structure, on economic growth.

Additionally, the elderly share increase in the working-age population is likely to reduce the geographical mobility and the national migration, all things being equal (GreenWood, 1997). Reduced voluntary mobility between/among jobs, as well as the older workers' geographical mobility, may reduce employment and productivity. It generally causes fewer matching people to jobs in which their skills may be used efficiently to diminish disparities in economic performance across regions. Thus, these mobility and flexibility issues may affect labour market performance, and therefore the economic dynamism.

A good deal of empirical evidence proved a positive effect of ageing working population on aggregate productivity. For instance, using five-year data from the OECD countries 1950-1990, Lindh, Malmberg (1999) demonstrated that the 50-64 age group has a positive influence on productivity (defined as GDP/Worker), and that the above 65 contribute negatively, while younger age groups have ambiguous effects. In addition, when estimated in the Tunisian context over the period 1965-2014, Frini and Ben Jedidia (2018) found that productivity declines at a young age (15-29), and rises at old age (50-64). However, the mechanism behind these age effects has not been resolved. The Tang and Macleod (2006) study on Canadian provinces 1981-2001, however, revealed that older workers have a modest negative impact on productivity.

\section{TUNISIAN DEMOGRAPHIC CHANGE AND CONSEQUENCES ON LABOUR MARKET}

\section{Demographic Shifts and Age Structure Change ${ }^{1}$}

A drastic demographic change has occurred in Tunisia following the decline of both mortality and fertility rates. During the period 1966-2016, the mortality rate fell from 35-40\% to a fairly constant low rate of 5.5\%. Fertility, which was close to eight children per woman in the early 60 's, has dropped below the renewal threshold ( 2.05 children per woman) since 1999. However, a slight increase has been recorded since 2010 to attain 2.4 children per woman in 2015. Life expectancy, which hardly exceeded 40 years in 1950, reached 75.4 years (78.1 years among women and 74.5 years among men) in 2016. This demographic transition has brought a deep change in the population age structure toward an irreversible ageing process. The age groups' proportions of $0-4$ and 5-14 have become less important. Over 1966-2015, they shifted from respectively $18.6 \%$ to $8.5 \%$ and from $27.9 \%$ to $14.9 \%$. In contrast, the share of the working-age population $15-59$ has increased from $48 \%$ to $64.4 \%$. However, this noteworthy change has affected the proportion of the over 60 -year-olds, which has further increased by more than two-fold to rise from $5.5 \%$ to $12.2 \%$.

Accordingly, these demographic changes have brought about a change in the labour force size and age structure. Meanwhile, the working-age population size growth declined from $2.5 \%$ to $1.7 \%$, while the growth rate of labour force went down from 1.8\% during 2004-2009 to 0.8\% during 2014-2017. However, the labour force participation rate has increased from about $44.9 \%$ to $49.6 \%$ during 1966 2014. Concurrently, the labour force average age rose progressively; the modal age evolved from the

1 Source of all quoted statistics is the Tunisian annual statistics of the National Institute of Statistics (NIS) from 1957-2016. 
25-29-year-olds in 2004 to the 30-34-year-olds in 2014. During 1984-2014, the share of the young labour force (15-29-year-olds) shrank significantly (from $49.8 \%$ to $30.3 \%$ ), the prime-aged adults share (30-49-year-olds) increased significantly (from 33.7\% to 52.7\%) and the share of the older labour force (50-64-year-olds) rose slightly (16.5\% to 17\%). Consequently, the share of the young employed population declined (from $35.6 \%$ to $29.7 \%$ ) while that of both prime-aged adults and elderly increased (respectively from $46.7 \%$ to $52.7 \%$ and from $17.6 \%$ to $17.6 \%$ ). The employed population is becoming older and older; the modal age has evolved from 20-24 to 30-34-year-olds. Likewise, the unemployed are getting older; the modal age shifted from the 15-19-year-olds to 25-29-year-olds. In 2011, about $50 \%$ of the unemployed were 25 -34-year-olds (34\% for those between 25 and 29 , and $16 \%$ who were aged $30-34$ ), and $38 \%$ were younger than 29 ( $10 \%$ were aged $15-19$ and $28 \%$ were aged $25-29$ ).

\section{Labour Productivity Shift}

Labour productivity is viewed to be below its potential level. As shown in diagram 1, the labour productivity growth has evolved irregularly over the past fifty years. The long-term productivity growth (over 1980-2010) has been estimated to be about 2.25\%. In the post-revolutionary period 2011-2014, it has reached its lowest levels due to the economic and social instability, which includes the low growth and job creation, and the sit-ins that have crippled the productive units. In 2013, the productivity loss was about $-0.6 \%$, as job creation was higher than economic growth (3.5\% against $2.8 \%){ }^{2}$

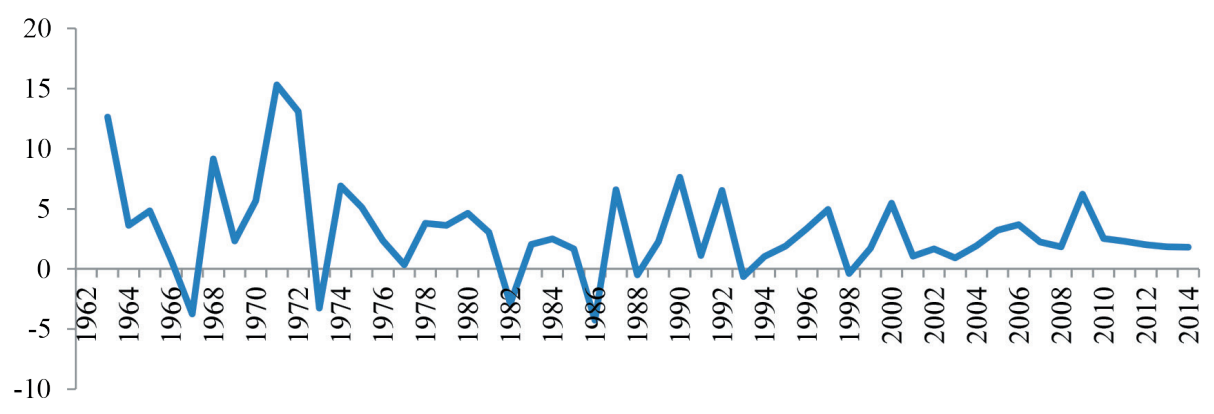

Diagram 1. Tunisian labour productivity growth change (1962-2014)

\section{MODEL AND DATA SPECIFICATION}

\section{Empirical model specification}

The previous literature review has allowed us to build our aggregate labour productivity model that refers to the augmented Solow model based on the work of Mankiw et al. (1992).

Labour productivity (Prod) can, generally, be calculated in several ways, such as the added value per number of workers or per worked hours, or as a marginal productivity. For our, estimate, we used the average labour productivity, as in the studies of Alexander (1993), Lindh and Malmberg (1999), Wakeford (2004), Tang and Macleod (2006) and Frini and Ben Jedidia (2018), because the marginal productivity or labour output per hour data are not available in Tunisia. It reflects labour productivity in terms of personal capacities of workers or the intensity of their effort. Its change reflects the combined effect of changes on both capital and technical efficiency, as well as the influence of economics of scale.

2 Data sources-the Tunisian Institute of Competitively and Quantitative Study (ITCQS) 2014. 
In order to assess the influence of ageing on labour productivity, we estimated the labour force age structure, as it is wholly economically involved in the labour market, which is not the case for the working-age population. Unlike the previous works, we were interested in the labour force rate by age structure to better capture the age effect over time. Different from the common definition of the labour force participation rate by age as a ratio of the labour force of age range per the overall working-age population (Mankiw, Romer \& Weil, 1992) or per total population (e.g. Barro \& Sala-i-Martin, 1992, Lindh \& Malmberg, 1999, Frini \& Ben Jedidia, 2018) or per employees (Brunow \& Hirte, 2006); we defined it for an age range as a share of the labour force per working-age population within the same age range. Explicitly, we distinguished three broad age ranges: young adulthood (15-29), prime-age adults (30-49) and old age (50-64), as in Frini and Ben Jedidia (2018) study on the Tunisian case but unlike them we reported to the working population of the same age range. Thus, we treated three labour force participation rates: that of the young (YL), adults (PL) and elderly (AL) as illustrated below.

$$
\mathrm{YL}=\frac{\text { Labor force aged } 15-29}{\text { Population aged } 15-29} ; \quad \mathrm{PL}=\frac{\text { Labor force aged } 30-49}{\text { Population aged } 30-49} ; \quad A L=\frac{\text { Labor force aged } 50-64}{\text { Population aged } 50-64} ;
$$

Together, these measurements reflect most of the age structure variation to allow the identification of distinct age effects. The age ranges that are not related to the labour market were considered as a reference age range. It should be noted that we considered 65 as the retirement age instead of 60 in order to foresee the impact of the retirement age delay as suggested by the government. Additionally, to make sure that the elderly who continue to work are not likely to be the most productive and those who have left are not the least productive, we undertook a robustness test by estimating a model with older workers aged 50-59. As we got the same result, we assumed that age retirement postponement would not artificially raise productivity.

Furthermore, as we were rather interested in labour productivity as a whole, we did not distinguish the labour force rate by gender.

In determining our economic variables, we estimated the influence of education, trade openness, investment, wage, and unemployment. By estimating the influence of education (E), we looked at a part of the human capital effect on productivity growth, the stock or accumulation of knowledge effect, and through the age distribution we looked at the other part, the transfer and implementation of new knowledge, through training or accumulated experience. We especially considered the enrolment rate at secondary education, for three reasons: (1) The unavailability of education level data for employees for all the period of study, (2) The enrolment rate data are only available for the population 5-11-yearolds, which is not suitable for our case study, and (3) The secondary level gives the most statistically significant result. We therefore chose it in order to win a freedom degree and overcome the multicollinearity problem. This is consistent with a labour market specificity characterized by a low human capital of employees. ${ }^{3}$

As in Lindh and Malmberg (1999), we considered trade openness (OP) to look into technology diffusion effect on productivity as stressed by literature.

Following Mankiw et al. (1992), we appraised the long-run gain in productivity of the capital accumulation (K) by considering the gross fixed capital formation (GFCF) at constant domestic prices.

In addition, we looked at the long-run dynamics relationship between labour productivity and wages, since it has been constantly a salient economic and legal concern. As a measure, we used the guaranteed industrial minimum wage (for the 40-hour regime) (W).

3 The average number of years-study of employees has evolved from 1.6 to 7.5 years during 1965-2014. 
Furthermore, because of the ambivalence relative to the connection between productivity growth and employment, we estimated the unemployment rate (U) in order to specify its nature for the Tunisian case (e.g. Blanchard et al., 1995; Gordon, 1997).

Finally, the baseline estimation equation takes the following form:

$$
\operatorname{Prod}_{t}=\alpha+\theta_{1} Y L_{t}+\theta_{2} P L_{t}+\theta_{3} A L_{t}+\theta_{4} E_{t}+\theta_{5} O P_{t}+\theta_{6} W_{t}+\theta_{7} K_{t}+\beta_{8} U_{t}+Z_{t}
$$

Where, $\mathrm{z}_{\mathrm{t}}$ is the error term.

In order to refine our empirical analysis, we estimated another model (model 2) with a time variable (DATE) to find out the effect of the structural changes that occurred after the revolution on the $14^{\text {th }}$ of January 2011.

\section{Data Construction}

Our annual time series were gathered from the National Institution of Statistics (NIS) and the Tunisian Institute of Competitively and Quantitative Study (ITCQS) data sources. Since their databases started after 1960 and were not up to date for at least two years, the longest possible time series covers the period 1965-2014. Moreover, these institutes could not provide a full series for all our variables. For this reason, we constructed our series for the labour force participation rate according to the three relevant age ranges and for education enrolment rate by level. For labour force participation rate by age range, we firstly calculated the size of the labour force and the size of the working-age population corresponding to each age range considered. Then, we divided the labour force population per workingage population for each age range.

For education, we reconsidered our data series computed in our previous published empirical work (as indicated in the Appendix) (Frini \& Muller, 2012). For trade openness, and as generally defined, we divided the sum of import and export by the GDP per capita at constant domestic prices.

The GFCF per capita at constant price measuring the capital accumulation $(\mathrm{K})$ was computed by dividing the GFCF per capita at current price per the consumption price index (base 1990) to avoid the prices effects.

Finally, we defined DATE as a dummy time variable equal to one if upper to 2010 and zero otherwise.

All variables are stated in logarithm so that the coefficients are interpreted as elasticities. Their primary statistical characteristics are displayed in Table 3 (in the Appendix). The model specification does not exhibit either correlation or multicollinearity problems as proved by the several check tests. ${ }^{4}$ Also, it does not lead to a heteroskedasticity issue, as the homoskedasticity is not rejected by the results of ARCH test (P-value of 0.65 for model 1 and of 0.49 for model 2). Likewise, this estimate does not imply a non-normal error as the Jarque-Berra test on the estimated residual does not reject the normality (P-value is of 0.986 for model 1 and of 0.856 for model 2).

\section{ECONOMETRIC METHODOLOGY AND ESTIMATION RESULTS}

Before performing our time series estimation, we tested the reliability of our time series data by testing the unit roots existence. The results of the Augmented Dickey-Fuller and of Philip-Perron tests

4 The Durbin-Watson test is inconclusive, as the test statistic value lies between $\mathrm{dL}$ and $\mathrm{dU}$ for the reference model ( $\mathrm{dL}$ $=1.20<\mathrm{DW}=1.687<\mathrm{dU}=1.93$ ). As Durbin-Watson test is not powerful in a statistical acceptance, we applied the Breusch Godfrey test, which presents a probability greater than $10 \%$ (p-value of 0.17 for model 1 ) and a low $\mathrm{R}^{2}$. Thus, we did not reject the null hypothesis of non-autocorrelated errors and consequently the model is free of autocorrelation. The same evidence is observed for model 2. 
used (Table 4, in the Appendix) ascertain that all the variables are integrated I (1). A cointegration VAR model, which required the variables be integrated of the same order, is then appropriate. ${ }^{5}$

\section{Cointegration Estimation}

Johansen and Jesulius (1990) maximum eigenvalue test was used to determine the cointegration ranks. We chose the model with no trend in the cointegration relation and the presence of a constant in the VEC, since such long-run equilibrium relationship between series does not have trends. The lag one was used referring to the VAR lag order selection by the Akaike information criterion. It was found that the maximum Eigen value test result (Table 5 in the Appendix) rejects the null hypothesis of no cointegration relationship at one percent level. ${ }^{6}$ There is a unique cointegration equation binding the variables together in a long-run equilibrium relationship characterized by a common trend.

$$
\begin{aligned}
\operatorname{Prod}=0.755- & 0.780 Y L+0.577 P L+1.06 A L+0.604 E+0.386 O P-0.115 W+0.227 K+0.308 U+Z_{t} \\
{[11.15] } & {[3.09][5.14] \quad[10.32][4.34] \quad[12.51] \quad[8.31][7.40] }
\end{aligned}
$$

Where, $\mathrm{z}_{\mathrm{t}}$ is the error term. T-statistics are presented in parentheses.

The long-run empirical evidence testified that the aggregate labour productivity in Tunisia is influenced by both economic and demographic factors. Even though we used a dissimilar measurement of labour force participation rate per age range compared to previous studies on Tunisia particularly Frini and Ben Jedidia (2018), we found the same evidence. Age structure impact on productivity is significant and non-monotonic. In Tunisia, productivity edges down at young age it increases for the prime age adult, and rises more toward the end of one's career. Thus, the overall age-productivity profile does not follow an inverted U-shape. In line with Dixon (2003), Cardoso et al. (2011), and Göbel and Zwick (2013), older workers are found to be productive. The aggregate labour productivity is positively affected by both prime-aged adult and old age. Better yet, the gains of labour productivity are rather boosted by the elder range of the labour force. The older workers seem to have been efficiently adapted to technological changes since they have experienced greater growth in tasks with an intense use of cognitive abilities (Autor et al., 2003). They have skills and capacities based on experience that many youngsters lack. Therefore, the older labourers may have higher average levels of work experience and positive effect on productivity thanks to skills and capacities. Such a result is consistent with the Tunisian productive system specificity, characterized mainly by the service sector, which does not require a high technological development. This is in line with Skirbekk (2003) conclusion stating that job performance increases when experience and verbal abilities are important.

However, analogous to Mahlberg et al. (2013a) findings, young workers weaken the labour productivity level. Although young workers have capabilities to become accustomed to technical progress, they require time to acquire the high skill (learning and training). Some years of experience are required to highlight the educational skills and gain significant education return. This fact is amplified by the low synergy between the educational system outcomes and the labour market needs.

Consequently, this empirical evidence shows an increasing productivity with age, which enables us to predict that labour productivity will not be adversely altered by the ageing process.

5 The cointegration technique is, however, built in a linear context. This linearity characteristic is considered restrictive insofar, as it implies a single long-run equilibrium and a symmetric adjustment to long-run target by the error correction model.

6 For model 2, two cointegration vectors were found. However, it exhibited the same results (note 2 in the Appendix). 
The findings related to the economic variables are, generally, in coherence with the theoretical expectations. Results display increasing returns of education on productivity. A potential productivity gain is embodied in the workers who accumulated human capital as emphasized by the human capital theory. Education is likely to raise workers productivity by providing useful knowledge and skills and the workers become more receptive to the new production processes. Thus, a higher educational attainment should help to maintain productivity as the labour force ages.

Furthermore, investment infers long-run gains in productivity. Capital accumulation improves the labour productivity, as it provides more capital per unit of labour, facilitates the effective use of new and powerful technologies, and raises workers productivity. Moreover, it could be pinpointed that the advent of new technology in the long-run, in turn, replaces labour and increases productivity.

Thereby, contrary to Mankiw et al. (1992), results of the empirical evidence point out a small weight of the physical capital but a large weight of human capital in explaining the output per worker variation.

In agreement with Alcala's and Ciccone (2004) interpretations, these potential productivity gains through physical and human capital accumulation are, also, reinforced by trade openness. Trade openness stimulates productivity in an environment of international competition thanks to technology transfer, gains stemming from economies of scale, and knowledge flows between countries.

Additionally, similar to Gordon's (1997) study results, there is a link between labour productivity and unemployment. A less volatile and more persistent positive correlation between productivity and unemployment was found as in Uhlig's (2006) work. Such a result confirms the neoclassical view, suggesting that a decline in labour demand increases productivity given the technical progress and wage setting. Nevertheless, the wage policy is likely to decrease productivity. This may be due to the Tunisian policy of "low wages", which promotes the rotation of the workforce and, consequently, presents a negative influence on the labour productivity in the long-run. Therefore, a reconsideration of the level of the minimum guaranteed wage of the industrial sector should be achieved in order to motivate workers to be more productive.

Interestingly, over the long-run, the structural and political change leads to a positive effect on productivity evolution (model 2).

\section{Estimation Vector Error Correction}

Thanks to the Vector Error Correction model, we estimated the diffusion speed of the labour force ageing on labour productivity by examining the adjustment mechanisms of the long-run relationships across variables (Engle \& Granger, 1987). The results (Tables 6 and 7 in the Appendix) show that the error correction term derived from the long-run cointegration relationship is highly significant and negative in the productivity equation. The short-run productivity evolution tends to join the long-run equilibrium. The adjustment towards equilibrium is swift, with a coefficient of -0.468 for model 1 and of -0.535 for model 2 . In the short-run, the labour productivity is independent of its lagged value, of labour age structure, and of the economic factors. Unlike the long-run, a negative short-run effect of the change brought about by the revolution of January 2011 was observed (Model 2). Such a finding denotes the dramatic economic situation resulting from the sit-ins and strikes that occurred in the productive sectors (mining industry).

In addition, we noted that only the lagged education variable influences labour productivity with an instantaneous negative effect. Education development did not efficiently contribute to the shortrun labour productivity growth process owing to three major raisons. Firstly, the Tunisian productive system is characterized by a low-educated labour force. With few education years, the labour force requires a long time to acquire the necessary skill and experience to be productive. Secondly, the 
educational system is inconsistent with the labour market requirement. As noted by Frini and Muller (2012), there is a low synergy between the educational system and labour market needs. Thirdly, the inability of the labour market to absorb the skilled labour force as revealed by the high unemployment rate of highly educated.?

Overall, this determinism between demographic, economic and productivity variables does not occur overnight but progressively; it is a long-run process. Consequently, labour productivity improvement requires a structural change in both labour force and economic conditions. Indeed, time is required for workers to adapt and acquire new skills and consequently to improve his productivity.

\section{CONCLUSION}

This paper underscored the population ageing impact on labour productivity in a macroeconomic perspective. It depicted the age-productivity profile in the Tunisian labour market by assessing the effects of three broad age ranges of the labour force participation rate of young adulthood, prime age and old age over the period 1965-2014.

The achieved findings pointed out that labour productivity is boosted thanks to economic factors (education, trade openness, capital accumulation and unemployment rate). But the appealing result is that productivity is, also, affected by demographic factors. Changes in the relative size of different age ranges have a noteworthy impact on the aggregate labour productivity. The results confirmed a strong long-run equilibrium relationship between labour productivity and labour force age structure. Interestingly, opposite to the widespread belief, older workers were consistently rated as having a more positive attitude, being more reliable, and displaying greater skills than young workers. Thus, the age-productivity profile does not follow an inverted U-shape. Productivity declines for young workers and rises when they enter the prime-adult age and go up further toward the end of their career. In this respect, ageing does not seem to lead to a low performance for the Tunisian labour market.

Nevertheless, the unfavourable scenario may come true with the arrival of the "baby-boom generation" to the retirement age after about a decade, if policy-makers do not manage the situation. If the Tunisian government does not respond appropriately to these demographic changes, it will face the risk that labour supply will shrink and labour productivity may not grow as quickly as needed to boost economic growth and increase living standards.

Finally, policies that affect labour market regulation and wage setting practices, retirement, pension rules, health care system, training, and education will be particularly critical for improving labour productivity. In light of our results, it appears that the retirement age delay beyond 60 years-old, as suggested by the government, is advised to gain more in labour productivity and enhance economic growth. Moreover, to keep a higher productivity level, older workers should be engaged only in jobs where experience and verbal ability are needed, and develop incentives for their training. Firms will have no choice but to expand their training programs to invest more in older employees and reorient the programs to meet the needs of those workers and strengthen the effectiveness of the professional training system. Similarly, policy-makers should invest in the workers' healthcare, and foster work environments in order to promptly take advantage of an ageing labour force, and enhance a continued productive participation of older workers.

7 Over 1966-2014, the graduates' unemployment rate has increased from $0.8 \%$ to $33.1 \%$. 


\section{REFERENCES}

Alcala, F., \& Ciccone, A. (2004). Trade and Productivity. Quarterly Journal of Economics, 119(2), 613-646. DOI:10.1162/0033553041382139

Alexander, C. O. (1993). The changing relationship between productivity, wages and unemployment in the UK. Oxford Bulletin of Economics and Statistics, 55(1), 87-102. DOI:10.1111/j.1468-0084.1993.mp55001005.x

Aubert, P., \& Crépon B. (2003). La productivité des salariés âgés : une tentative d’estimation. Economie et statistique, 368, 95-119.

Aubert, P., \& Crépon B. (2004). Les salariés âgés sont-ils moins productifs ? Gérontologie et société, 27(111) DOI:10.3917/gs.111.0095

Aubert, P., \& Crépon, B. (2006). Age, wage and productivity: Firm-level evidence, Discussion Paper INSEE, Paris. Retrieved September 30, 2018, from https://pdfs.semanticscholar.org/53c8/bbcc61640227635def7cb5d8778dc734e102.pdf

Autor, D., Levy, F., \& Murnane, R. J. (2003). The Skill Content of Recent Technological Change: An Empirical Exploration. Quarterly Journal of Economics, 18(4), 1279-1333. DOI:10.3386/w8337

Barro, R., \& Sala-i-Martin, J. X. (1992). Convergence. Journal of Political Economy, 100(2), 223-251.

Barro, R., \& Sala-i-Martin, J. X. (1995). Technological Diffusion, Convergence, and Growth. NBER Working Paper No. 5151

Blanchard, O., Solow, R., \& Wilson, B.A. (1995). Productivity and Unemployment. Mimeo: Massachusetts Institute of Technology.

Bloom, D.E., \& Sousa-Poza, A. (2013). Ageing and Productivity: Introduction. PGDA Working Paper 98. Retrieved September 30, 2018, from https://cdn1.sph.harvard.edu/wp-content/uploads/sites/1288/2013/10/ PGDA_WP_98.pdf

Bloom, D.E., \& Williamson, J. (1998). Demographic Transitions and Economic Miracles in Emerging Asia. World Bank Economic Review, 12, 419-56.

Börsch-Supan, A. (2003). Labour Market Effects of Population Aging. Labour, 17(1), 5-44. DOI:10.1111/14679914.17.specialissue.2

Bös, D., \& von Weizsäcker, R. K. (1989). Economic consequences of an aging population. European Economic Review, 33(2-3), 345-354. DOI:10.1016/0014-2921(89)90112-8

Brunow, S., \& Hirte, G. (2006). Age structure and regional economic growth. Review of Regional Research, 26(1), 3-23.

Brunow, S., \& Hirte, G. (2008). The Age Pattern of Human Capital and Regional Productivity. Dresden Discussion Paper in Economics, No. 01/08, Technische Universität Dresden, Faculty of Business and Economics, Department of Economics.

Cadiou, L., Genet, J., \& Guérin, J. L. (2002). Évolutions démographiques et marché du travail: des liens complexes parfois contradictoires. Economie et statistique, 355(1), 139-156.

Cardoso, A.R., Guimaraes, P., \& Varejão, J. (2011). Are older workers worthy of their pay? An empirical investigation of age-productivity and age-wage nexuses. De Economist, 159, 95-111. DOI:10.1007/s10645-011-9163-8

Chawla, M., Betcherman, G., \& Banerji, A. (2012). From Red to Gray: The «Third Transition» of Aging Populations in Eastern Europe and the Former Soviet Union. Washington, DC: World Bank.

Crépon, B., Deniau, N., \& Pérez-Duarte S. (2002). Wages, Productivity, and Worker Characteristics: A French Perspective. Mimeo. INSEE.

De Grip, A., \& Van Loo, J. (2002). The economics of skills obsolescence: A review, in A. de Grip, J. van Loo, K. Mayhew (Ed.), Economics of skills obsolescence: Theoretical innovations and empirical applications (pp. 1-26). Bingley: Emerald Group Publishing Limited.

Disney, R. (1996). Can we afford to grow older? A perspective on the economics of aging. Cambridge, MA: MIT Press. 
Dixon, S. (2003). Implications of population ageing for the labour Market. Labour Market Division, Office for National Statistics. Labour Market trends.

Engle, R. F., \& Granger, C. W. J. (1987). Co-integration and Error Correction: Representation, Estimation, and Testing. Econometrica, 55(2), 251-276.

Frini, O., \& Ben Jedidia, K. (2018). The age structure change of population and labour productivity impact. Economics Bulletin, 38(4), 1831-1844.

Frini, O., \& Muller, C. (2012). Demographic Transition, Education and Economic Growth in Tunisia. Economic Systems, 36(3), 351-371. DOI:10.1016/j.ecosys.2012.04.002

Göbel, C., \& Zwick, T. (2009). Age and productivity - evidence from linked employer employee data. ZEW - Centre for European Economic Research Discussion Paper No. 09-020. DOI:10.2139/ssrn.1431878

Göbel, C., \& Zwick, T. (2012). Age and Productivity: Sector Differences. De Economist, 160(1), 35-57. DOI:10.1007/ s10645-011-9173-6

Göbel, C., \& Zwick, T. (2013). Are Personnel Measures Effective in Increasing Productivity of Old Workers? Labour Economic, 22(C), 80-93.

Gordon, R. J. (1997). Is there a trade-off between unemployment and productivity growth? In D. Snower and G. de la Dehesa (Ed.), Unemployment policy: Government options for the labour market (pp. 433-463). Cambridge: Cambridge University Press.

Greenwood, M. (1997). Internal migration in developed countries. In M. R. Rosenzweig and O. Stark (Ed.), Handbook of population and family economics (pp. 647-720). Amsterdam: Elsevier.

Gregg, P., \& Wadsworth, J. (1999). Job tenure, 1975-1998. In P. Gregg and J. Wadsworth (Ed.), The state of working Britain (pp. 109-126). New York: Manchaster University Press.

Haltivanger, J. C., Lane, J. I., \& Spletzer, J. R. (1999). Productivity Differences Across Employers. The Roles of Employer Size, Age and Human Capital. American Economic Review Papers and Proceedings, 89(2), 94-98.

Ilmakunnas, P., Maliranta, M. \& Vainiomäki, J. (2004). The roles of employer and employee characteristics for plant productivity. Journal of Productivity Analysis, 21(3), 249-276. DOI:10.1023/B:PROD.0000022093.59352.5e

Johansen, S., \& Juselius, K. (1990). Maximum likelihood estimation and inference on cointegration - with applications to money demand. Oxford Bulletin of Economics and Statistics, 52(2), 169-210. DOI:10.1111 /j.1468-0084.1990.mp52002003.x

Lindh, T., \& Malmberg, B. (1999). Age structure effects and growth in the OECD, 1950-1990. Journal of Population Economics, 12(3), 431-449.

Mahlberg, B., Freund, I., \& Prskawetz, A. (2013a). Ageing, productivity and wages in Austria: Sector level evidence. Empirica, 40(4), 561-584.

Mahlberg, B., Inga, F., Cuaresma, J-C., \& Prskawetz, L. (2013b). Ageing, productivity and wages in Austria. Labour Economics, 22, 5-15. DOI:10.1016/j.labeco.2012.09.005

Malmberg, B., Lindh,T. \& Halvarsson, M. (2008). Productivity consequences of workforce ageing - Stagnation or a Horndal effect? In A. Prskawetz, D. Bloom, and W. Lutz (Ed.), Population Aging, Human Capital Accumulation and Productivity Growth, Population and Development Review (pp. 238-256). New York: Population Council.

Mankiw, N. G., Romer, D., \& Weil, D. N. (1992). A contribution to the empirics of economic growth. The Quarterly Journal of Economics, 107(2), 407-437.

Peng, X. (2006). Macroeconomic Consequences of Population Ageing in China-A Computable General Equilibrium Analysis. Journal of Population Research, 30(4), 12-22.

Prskawetz, A., Mahlberg, B., \& Skirbekk. V. (2007). Firm Productivity, Workforce Age and Educational Structure in Austrian industries in 2001. In R. Clark, N. Ogawa and A. Mason (Ed.), Population Aging, Intergenerational Transfers and the Macroeconomy (pp. 38-66). Cheltenham: Edward Elgar Publishing.

Rožman, M., Treven,T., \& Cancer, V. (2016). Stereotypes of older employees compared to younger employees in Slovanian companies. Management, 21(1), 165-179. 
Skirbekk, V. (2003). Age and individual productivity: a literature survey. Vienna Yearbook of Population Research, 2, 133-153.

Skirbekk, V. (2008). Age and Productivity Capacity: Descriptions, Causes and Policy Options. Ageing Horizons, $8,4-12$.

Tang, J., \& MacLeod, C. (2006). Labour force ageing and productivity performance in Canada. Canadian Journal of Economics, 39(2), 582-603.

Tanner, S. (1997). The dynamics of retirement behaviour. In The Dynamics of Retirement: Analyses of the Retirement Surveys. R. Disney, E. Grundy, and P. Johnson (Ed.), Department of Social Security Research Report No. 72. London: Stationery Office.

Uhlig, H. (2006). Regional Labor Markets, Network Externalities and Migration: The Case of German Reunification. American Economic Review Papers \& Proceedings, 96(2), 383-387.

Van Ours, J. C., \& Stoeldraijer, L. (2010). Age, Wage and Productivity. Bonn: IZA.

Verhaeghen, P., \& Salthouse, T. A. (1997). Meta-Analyses of Age-Cognition Relations in Adulthood: Estimates of Linear and Nonlinear Age Effects and Structural Models. Psychological Bulletin, 122(3), 231-249.

Vodopivec, M., \& Arunatilake, N. (2008). Population aging and the labor market: the case of Srilanka. Retrieved September 30, 2018, from http://siteresources.worldbank.org/SOCIALPROTECTION/Resources/SPDiscussion-papers/Labor-Market-DP/0821.pdf

Wakeford, J. (2004). The productivity-wage relationship in South Africa: an empirical investigation. Development Southern Africa, 21(1), 109-132. 
APPENDIX

\begin{tabular}{lccccccccc}
\hline & PROD & $Y L$ & $P L$ & $A L$ & $K$ & OP & $E$ & $W$ & $U$ \\
\hline Mean & 8.649 & 3.847 & 4.060 & 3.791 & 8.015 & 4.307 & 3.664 & 4.350 & 2.726 \\
\hline Median & 8.650 & 3.847 & 4.074 & 3.792 & 8.071 & 4.419 & 3.710 & 4.677 & 2.747 \\
\hline Maximum & 9.280 & 3.956 & 4.188 & 3.933 & 8.787 & 4.738 & 4.254 & 5.615 & 2.923 \\
\hline Minimum & 7.854 & 3.668 & 3.854 & 3.682 & 7.006 & 3.459 & 2.737 & 2.578 & 2.517 \\
\hline Std. Dev. & 0.392 & 0.061 & 0.083 & 0.070 & 0.506 & 0.330 & 0.491 & 1.001 & 0.074 \\
\hline Observations & 50 & 50 & 50 & 50 & 50 & 50 & 50 & 50 & 50 \\
\hline
\end{tabular}

Table 3. Descriptive Statistics Variables

\begin{tabular}{ccccccc}
\hline \multicolumn{7}{c}{ The Probability value of the unit roots tests (P-value) } \\
\hline \multicolumn{7}{c}{ Augmented Dickey Fuller (ADF) } \\
\hline \multicolumn{7}{c}{ Phillips Perron (PP) } \\
\hline Model & Model (1) & Model (2) & Model (3) & Model (1) & Model (2) & Model (3) \\
\hline Prod & 1.000 & 0.479 & 0.496 & 1.000 & 0.577 & 0.516 \\
YL & 0.518 & 0.241 & 0.025 & 0.833 & 0.049 & 0.005 \\
PL & 0.999 & 0.999 & 0.049 & 0.987 & 0.265 & 0.049 \\
AL & 0.335 & 0.761 & 0.452 & 0.376 & 0.761 & 0.239 \\
E & 0.986 & 0.752 & 0.980 & 0.999 & 0.381 & 0.815 \\
W & 0.995 & 0.273 & 0.987 & 0.999 & 0.432 & 0.968 \\
K & 0.961 & 0.236 & 0.157 & 0.981 & 0.661 & 0.607 \\
OP & 0.970 & 0.146 & 0.384 & 0.973 & 0.125 & 0.535 \\
U & 0.421 & 0.033 & 0.654 & 0.660 & 0.033 & 0.081 \\
\hline \multicolumn{7}{c}{ First difference ( 4$)$} \\
Prod & 0.117 & 0.000 & 0.000 & 0.000 & 0.000 & 0.000 \\
YL & 0.000 & 0.018 & 0.048 & 0.000 & 0.003 & 0.008 \\
PL & 0.000 & 0.000 & 0.000 & 0.000 & 0.000 & 0.000 \\
AL & 0.000 & 0.000 & 0.001 & 0.000 & 0.000 & 0.000 \\
E & 0.026 & 0.001 & 0.008 & 0.000 & 0.001 & 0.008 \\
W & 0.029 & 0.011 & 0.018 & 0.002 & 0.000 & 0.001 \\
K & 0.000 & 0.004 & 0.020 & 0.000 & 0.004 & 0.018 \\
OP & 0.000 & 0.000 & 0.000 & 0.000 & 0.000 & 0.000 \\
U & 0.000 & 0.000 & 0.000 & 0.000 & 0.000 & 0.000 \\
\hline
\end{tabular}

Table 4. Unit Root Tests*

${ }^{*}$ Model (1) with no intercept and no deterministic trend: $\Delta \mathrm{X}_{\mathrm{t}}=(\rho-1) \mathrm{X}_{\mathrm{t}-1}+\sum_{\mathrm{j}}^{\mathrm{k}} \theta_{\mathrm{j}} \Delta \mathrm{X}_{\mathrm{t}-\mathrm{j}}+\varepsilon_{t}$

Model (2) with intercept and no deterministic trend: $\Delta X_{t}=(\rho-1) X_{t-1}+v+\sum_{j}^{k} \theta_{j} \Delta X_{t-j}+\varepsilon_{t}$

Model (3) with intercept and deterministic trend: $\Delta X_{t}=(\rho-1) X_{t-1}+\lambda+\delta t+\sum_{j}^{k} \theta_{j} \Delta X_{t-j}+\varepsilon_{t}$

Both the $\mathrm{ADF}$ and the PP tests take the unit root as the null hypothesis $\mathrm{H}_{0}: \rho=1$. This null hypothesis is tested against the one side alternative $\mathrm{H}_{1} \rho<0$. 


\begin{tabular}{|c|c|c|c|c|c|}
\hline \multicolumn{3}{|c|}{ Base regression: Model 1} & \multicolumn{3}{|c|}{ Model 2} \\
\hline $\begin{array}{c}H_{0}: \text { r or fewer } \\
\text { cointegration } \\
\text { vectors }\end{array}$ & Eigen Value & $P$-value ${ }^{\star *}$ & $\begin{array}{c}H_{o}: \text { ror fewer } \\
\text { cointegration } \\
\text { vectors }\end{array}$ & Eigen Value & $P$-value $e^{\star *}$ \\
\hline None $^{*}$ & 0.823 & 0.000 & None ${ }^{\star}$ & 0.679 & 0.029 \\
\hline At most 1 & 0.654 & 0.068 & At most $1^{\star}$ & 0.618 & 0.049 \\
\hline At most 2 & 0.561 & 0.217 & At most 2 & 0.525 & 0.141 \\
\hline At most 3 & 0.527 & 0.133 & At most 3 & 0.496 & 0.065 \\
\hline At most 4 & 0.486 & 0.082 & At most $4^{*}$ & 0.449 & 0.036 \\
\hline At most 5 & 0.331 & 0.387 & At most 5 & 0.260 & 0.328 \\
\hline At most 6 & 0.290 & 0.198 & At most 6 & 0.229 & 0.093 \\
\hline At most 7 & 0.150 & 0.395 & At most $7^{*}$ & 0.111 & 0.017 \\
\hline At most 8 & 0.068 & 0.065 & & & \\
\hline
\end{tabular}

Table 5. Maximum Eigenvalue Test

Max-eigenvalue test indicates 1 cointegrating eqn (s) at the 0.05 level for model 1

Max-eigenvalue test indicates 2 cointegrating eqn (s) at the 0.05 level for model 2

*denotes rejection of the hypothesis at the 0.05 level

${ }^{* *}$ MacKinnon-Haug-Michelis (1999) p-values

\begin{tabular}{lccccccccc}
\hline & $\boldsymbol{D}($ Prod $)$ & $D(Y L)$ & $D(P L)$ & $D(A L)$ & $D(E)$ & $D(W)$ & $D(K)$ & $D(O P)$ & $D(U)$ \\
\hline Error & -0.468 & -0.160 & -0.019 & 0.202 & -0.113 & -0.066 & 0.306 & 1.082 & 0.381 \\
Correction & $(-3.595)$ & $(-2.132)$ & $(-0.156)$ & $(2.149)$ & $(-0.765)$ & $(-0.233)$ & $(0.891)$ & $(2.636)$ & $(1.246)$ \\
term ECT1 & & & & & & & & & \\
\hline Regressors & 0.041 & 0.166 & 0.093 & -0.034 & 0.030 & -0.232 & 0.082 & -0.167 & -0.171 \\
D(Prod (-1)) & $(0.280)$ & $(1.967)$ & $(0.663)$ & $(-0.329)$ & $(0.186)$ & $(-0.726)$ & $(0.213)$ & $(-0.362)$ & $(-0.499)$ \\
& 0.360 & 0.403 & 0.084 & 0.038 & 0.120 & -0.165 & 0.242 & -0.054 & 0.037 \\
$\mathrm{D}(\mathrm{YL}(-1))$ & $(1.650)$ & $(3.193)$ & $(0.404)$ & $(0.381)$ & $(0.487)$ & $(-0.347)$ & $(0.419)$ & $(-0.079)$ & $(0.072)$ \\
& -0.175 & 0.205 & -0.431 & 0.482 & -0.314 & 0.147 & -0.158 & 0.397 & -0.224 \\
$\mathrm{D}(\mathrm{PL}(-1))$ & $(-0.832)$ & $(1.679)$ & $(-2.135)$ & $(3.158)$ & $(-1.315)$ & $(0.320)$ & $(-0.284)$ & $(0.596)$ & $(-0.452)$ \\
& -0.430 & 0.223 & -0.308 & 0.106 & -0.088 & -0.534 & -0.158 & 0.189 & 0.061 \\
$\mathrm{D}(\mathrm{AL}(-1))$ & $(-1.868)$ & $(1.674)$ & $(-1.400)$ & $(0.635)$ & $(-0.339)$ & $(-1.064)$ & $(-0.284)$ & $(0.261)$ & $(0.114)$ \\
& $-\mathbf{0 . 6 6 6}$ & -0.001 & 0.068 & -0.042 & 0.410 & -0.038 & 0.045 & 0.660 & 0.224 \\
$\mathrm{D}(\mathrm{E}(-1))$ & $\mathbf{- 4 . 4 8 1 )}$ & $(-0.014)$ & $(0.478)$ & $(-0.390)$ & $(2.432)$ & $(-0.117)$ & $(0.312)$ & $(1.408)$ & $(0.642)$ \\
& -0.060 & -0.023 & -0.090 & 0.086 & 0.036 & 0.346 & -0.029 & -0.229 & -0.006 \\
$D(W(-1))$ & $(-0.872)$ & $(-0.577)$ & $(1.373)$ & $(1.737)$ & $(0.406)$ & $(2.304)$ & $(-0.160)$ & $(-1.053)$ & $(-0.037)$ \\
& -0.078 & -0.031 & -0.039 & -0.003 & -0.027 & 0.213 & 0.494 & 0.071 & 0.049 \\
$D(K(-1))$ & $(-1.222)$ & $(-0.845)$ & $(-0.650)$ & $(-0.070)$ & $(-0.371)$ & $(1.525)$ & $(2.920)$ & $(0.353)$ & $(0.327)$ \\
& 0.038 & -0.015 & 0.033 & 0.026 & -0.007 & 0.102 & 0.266 & 0.256 & 0.186 \\
$D(O P(-1))$ & $(0.716)$ & $(-0.481)$ & $(0.649)$ & $(0.669)$ & $(-1.144)$ & $(0.867)$ & $(1.864)$ & $(1.504)$ & $(1.468)$ \\
& -0.034 & -0.029 & 0.014 & 0.011 & -0.014 & 0.023 & 0.089 & 0.200 & -0.075 \\
$D(U(-1))$ & $(-0.491)$ & $(-0.717)$ & $(0.215)$ & $(0.223)$ & $(-0.181)$ & $(0.151)$ & $(0.486)$ & $(0.907)$ & $(-0.458)$ \\
& 0.053 & 0.001 & 0.009 & -0.009 & 0.016 & 0.035 & 0.008 & 0.010 & -0.006 \\
$\mathrm{C}$ & $(6.297)$ & $(-0.369)$ & $(1.213)$ & $(-1.554)$ & $(1.730)$ & $(1.910)$ & $(0.390)$ & $(0.373)$ & $(-0.317)$ \\
\hline $\mathrm{R}^{2}$ & $\mathbf{0 . 4 8 4}$ & 0.480 & 0.184 & 0.363 & 0.400 & 0.306 & 0.370 & 0.214 & 0.103 \\
\hline
\end{tabular}

Table 6. Vector Error Correction base regression: Model 1

Notes: Students' $t$ is in parentheses. 
Note2: Model (2)

First cointegration equation Model 2 Prod $=0.659-0.565 Y L+0.494 P L+0.70 A L+0.620 E-0.143 W+0.202 K+0.043 O P+0.3176 U+0.074 D A T E+Z_{t}$
$[6.58] \quad[2.72] \quad[3.56] \quad[11.41] \quad[5.79] \quad[10.95] \quad[9.38] \quad[3.01] \quad[3.36]$

\begin{tabular}{|c|c|c|c|c|c|c|c|c|c|c|}
\hline & $\begin{array}{c}D \\
\text { (Prod) }\end{array}$ & $\begin{array}{c}D \\
(Y L)\end{array}$ & $\begin{array}{c}D \\
(P L)\end{array}$ & $\begin{array}{c}D \\
(A L)\end{array}$ & $\begin{array}{l}D \\
(E)\end{array}$ & $\begin{array}{c}D \\
(W)\end{array}$ & $\begin{array}{c}D \\
(K)\end{array}$ & $\begin{array}{c}D \\
(O P)\end{array}$ & $\begin{array}{c}D \\
(U)\end{array}$ & $\begin{array}{c}D \\
(D A T E)\end{array}$ \\
\hline $\begin{array}{l}\text { Error } \\
\text { Correc- } \\
\text { tion term } \\
\text { ECT1 }\end{array}$ & $\begin{array}{c}-0.535 \\
(-4.500)\end{array}$ & $\begin{array}{c}-0.151 \\
(-2.008)\end{array}$ & $\begin{array}{c}-0.110 \\
(-0.901)\end{array}$ & $\begin{array}{c}0.154 \\
(1.621)\end{array}$ & $\begin{array}{c}0.054 \\
(0.379)\end{array}$ & $\begin{array}{c}-0.019 \\
(-0.069)\end{array}$ & $\begin{array}{c}0.212 \\
(0.615)\end{array}$ & $\begin{array}{c}1.026 \\
(2.491)\end{array}$ & $\begin{array}{c}0.447 \\
(1.485)\end{array}$ & $\begin{array}{c}1.294 \\
(1.875)\end{array}$ \\
\hline $\begin{array}{l}\text { Regresso } \\
D \text { (Prod }\end{array}$ & $(0.138)$ & & & & $\begin{array}{c}-0.046 \\
(-0.297)\end{array}$ & $\begin{array}{c}-0.258 \\
(-0.826)\end{array}$ & $\begin{array}{c}0.145 \\
(0.381)\end{array}$ & $\begin{array}{c}-0.045 \\
(-0.100)\end{array}$ & $\begin{array}{c}-0.162 \\
(-0.490)\end{array}$ & $\begin{array}{c}-0.615 \\
(-0.807)\end{array}$ \\
\hline & & $\begin{array}{l}(0.336) \\
(2.495)\end{array}$ & $\begin{array}{l}0.0173 \\
(0.079)\end{array}$ & & & & $\begin{array}{c}0.323 \\
(0.524)\end{array}$ & $\begin{array}{c}0.396 \\
(0.539)\end{array}$ & $\begin{array}{c}0.217 \\
(0.403)\end{array}$ & $\begin{array}{c}0.371 \\
(0.301)\end{array}$ \\
\hline & -0.307 & 0.194 & -0.499 & 0.501 & -0.293 & & -0.190 & 0.470 & -0.179 & 0.218 \\
\hline $\mathrm{D}(\mathrm{PL}(-1))$ & $\begin{array}{c}(-1.523) \\
-0.419\end{array}$ & $\begin{array}{c}(1.514) \\
0.235\end{array}$ & $\begin{array}{c}(-2.402) \\
-0.316\end{array}$ & $\begin{array}{c}(3.102) \\
0.102\end{array}$ & $\begin{array}{c}(-1.216) \\
-0.107\end{array}$ & $\begin{array}{c}(0.287) \\
-0.543\end{array}$ & $\begin{array}{c}(-0.324) \\
0.015\end{array}$ & $\begin{array}{c}(0.673) \\
0.103\end{array}$ & $\begin{array}{c}(-0.350) \\
0.018\end{array}$ & $\begin{array}{l}(0.186) \\
-0.150\end{array}$ \\
\hline D & $(-1.959)$ & (1.735) & $(-1.436)$ & $(0.597)$ & $(-0.421)$ & $(-1.067)$ & (0.024) & & & \\
\hline $\mathrm{D}(\mathrm{E}(-1))$ & $\begin{array}{c}-0.644 \\
(-5.019)\end{array}$ & & & $\begin{array}{c}-0.090 \\
(-0.880)\end{array}$ & $\begin{array}{c}0.497 \\
(3.241)\end{array}$ & & & & $\begin{array}{c}0.193 \\
(0.594)\end{array}$ & $\begin{array}{c}0.208 \\
(0.279)\end{array}$ \\
\hline$D(W(-1))$ & $\begin{array}{c}-0.051 \\
(-0.812)\end{array}$ & $\begin{array}{c}-0.020 \\
(-0.497)\end{array}$ & $\begin{array}{c}-0.089 \\
(-1.358)\end{array}$ & $\begin{array}{c}0.084 \\
(1.645)\end{array}$ & $\begin{array}{c}0.034 \\
(0.448)\end{array}$ & & $\begin{array}{c}-0.033 \\
(-0.183)\end{array}$ & $\begin{array}{c}-0.248 \\
(-1.120)\end{array}$ & $\begin{array}{c}-0.014 \\
(-0.090)\end{array}$ & $\begin{array}{c}-0.152 \\
(-0.411)\end{array}$ \\
\hline$D(K(-$ & $\begin{array}{c}-0.061 \\
(-1.072)\end{array}$ & $\begin{array}{c}-0.020 \\
(-0.563)\end{array}$ & $\begin{array}{c}-0.052 \\
(-0.888)\end{array}$ & $\begin{array}{c}-0.021 \\
(-0.471)\end{array}$ & $\begin{array}{c}0.001 \\
(0.017)\end{array}$ & $\begin{array}{c}0.223 \\
(1.647)\end{array}$ & $\begin{array}{c}0.462 \\
(2.804)\end{array}$ & $\begin{array}{c}-0.002 \\
(-0.011)\end{array}$ & $\begin{array}{c}0.034 \\
(0.238)\end{array}$ & $\begin{array}{c}0.215 \\
(0.652)\end{array}$ \\
\hline$D(\mathrm{OF}$ & $\begin{array}{c}0.019 \\
(0.379)\end{array}$ & $\begin{array}{c}-0.018 \\
(-0.575)\end{array}$ & $\begin{array}{c}0.020 \\
(0.389)\end{array}$ & $\begin{array}{c}0.021 \\
(0.523)\end{array}$ & $\begin{array}{c}-0.038 \\
(-0.633)\end{array}$ & $\begin{array}{c}0.111 \\
(0.913)\end{array}$ & $\begin{array}{c}0.262 \\
(1.761)\end{array}$ & $\begin{array}{c}0.283 \\
(1.589)\end{array}$ & $\begin{array}{c}0.213 \\
(1.639)\end{array}$ & $\begin{array}{c}0.493 \\
(1.651)\end{array}$ \\
\hline$D(U(-1))$ & $\begin{array}{c}0.179 \\
(1.493)\end{array}$ & $\begin{array}{c}-0.019 \\
(-0.250)\end{array}$ & $\begin{array}{c}0.078 \\
(0.631)\end{array}$ & $\begin{array}{c}-0.097 \\
(-1.016)\end{array}$ & $\begin{array}{c}0.218 \\
(1.525)\end{array}$ & $\begin{array}{c}0.136 \\
(0.480)\end{array}$ & $\begin{array}{c}0.111 \\
(0.320)\end{array}$ & $\begin{array}{c}0.145 \\
(0.351)\end{array}$ & $\begin{array}{c}0.011 \\
(0.037)\end{array}$ & $\begin{array}{c}-0.203 \\
(-0.292)\end{array}$ \\
\hline $\begin{array}{l}D(D A T E \\
(-1))\end{array}$ & $\begin{array}{c}-0.108 \\
(-2.090)\end{array}$ & $\begin{array}{c}-0.003 \\
(-0.104)\end{array}$ & $\begin{array}{c}-0.038 \\
(-0.709)\end{array}$ & $\begin{array}{c}0.050 \\
(1.200)\end{array}$ & $\begin{array}{c}-0.104 \\
(-1.676)\end{array}$ & $\begin{array}{c}-0.053 \\
(-0.430)\end{array}$ & $\begin{array}{c}-0.019 \\
(-0.126)\end{array}$ & $\begin{array}{c}0.017 \\
(0.095)\end{array}$ & $\begin{array}{c}-0.041 \\
(-0.311)\end{array}$ & $\begin{array}{c}0.143 \\
(0.475)\end{array}$ \\
\hline $\mathrm{C}$ & $\begin{array}{c}0.056 \\
(7.078) \\
\end{array}$ & $\begin{array}{c}-0.002 \\
(-0.458)\end{array}$ & $\begin{array}{l}0.0125 \\
(1.525) \\
\end{array}$ & $\begin{array}{c}-0.009 \\
(-1.494)\end{array}$ & $\begin{array}{c}0.016 \\
(1.709) \\
\end{array}$ & $\begin{array}{c}0.035 \\
(1.889)\end{array}$ & $\begin{array}{c}0.011 \\
(0.512)\end{array}$ & $\begin{array}{c}0.013 \\
(0.489) \\
\end{array}$ & $\begin{array}{c}-0.005 \\
(-0.261)\end{array}$ & $\begin{array}{c}0.016 \\
(0.363) \\
\end{array}$ \\
\hline $\mathrm{R}^{2}$ & 0.568 & 0.476 & 0.208 & 0.347 & 0.441 & 0.309 & 0.365 & 0.207 & 0.127 & 0.137 \\
\hline
\end{tabular}

Table 7. Vector Error Correction: Model 2

Notes: Students' $t$ is in parentheses. 


\begin{tabular}{|c|c|c|c|c|c|c|c|c|c|}
\hline \multicolumn{10}{|l|}{ Data base } \\
\hline years & Prod & YL & PL & Al & $\mathbf{E}$ & $\mathbf{K}$ & OP & $\mathbf{U}$ & W \\
\hline 1965 & 2656.750 & 39.21000 & 7.22000 & 46.29000 & 15.45000 & 1222.264 & 33.44200 & 15.10000 & 13.17333 \\
\hline 1966 & 2676.850 & 40.55000 & 8.50000 & 48.50000 & 17.73000 & 1104.089 & 34.52800 & 15.20000 & 4.56000 \\
\hline 1967 & 76.720 & 42.00000 & 8.42000 & 48.42000 & 18.87000 & 1119.283 & 35.73600 & 15.30000 & 4.56000 \\
\hline 1968 & 2812.350 & 43.32000 & 8.72000 & 48.72000 & 20.10000 & 1105.777 & 31.78600 & 15.40000 & 4.56000 \\
\hline 1969 & 2878.190 & 44.64000 & 9.00000 & 49.00000 & 22.40000 & 1182.591 & 34.80500 & 15.50000 & 4.56000 \\
\hline 1970 & 3041.320 & 46.40000 & 53.95000 & 53.95000 & 23.70000 & 1282.195 & 46.74400 & 15.60000 & 14.56000 \\
\hline 1971 & 3506.910 & 47.84000 & 4.92000 & 54.92000 & 23.00000 & 1412.188 & 48.53600 & 15.70000 & 16.78794 \\
\hline 1972 & 3966 & 48.74000 & 56.56000 & 56.56000 & 22.03000 & 1612.400 & 50.08800 & 15.80000 & 8.02667 \\
\hline 1973 & 3837.170 & 49.60000 & 58.02000 & 58.02000 & 21.20000 & 1624.627 & 52.47100 & 15.90000 & 18.0 \\
\hline 1974 & 4101.970 & 50.42000 & 9.34000 & 59.34000 & 20.54000 & 1914.248 & 67.57300 & 16.10000 & 271 \\
\hline 1975 & 4311.440 & 52.18000 & 5.20000 & 55.20000 & 20.61000 & 2390.326 & 63.96000 & 16.20000 & 540 \\
\hline 1976 & 4412.970 & 52.00000 & 4.35000 & 54.35000 & 20.94000 & 2732.675 & 63.09800 & 15.90000 & 333 \\
\hline 1977 & 4427.920 & 50.62000 & 2.67000 & 52.67000 & 22.10000 & 2754.508 & 67.59400 & 15.70000 & 32.66557 \\
\hline 1978 & 4596.390 & 47.43000 & 5.98000 & 55.98000 & 23.11000 & 2889.681 & 69.70000 & 15.60000 & 35.83800 \\
\hline 1979 & 4763.000 & 48.20000 & 55.28000 & 55.28000 & 23.64000 & 3095.490 & 80.94700 & 15.50000 & 39.14521 \\
\hline 1980 & 4983.220 & 48.82000 & 5.81000 & 55.81000 & 25.87000 & 3217.178 & 85.83800 & 15.40000 & 44.39739 \\
\hline 1981 & 5135.231 & 50.11000 & 6.24000 & 56.24000 & 28.88000 & 3674.390 & 91.21000 & 15.30000 & 584 \\
\hline 1982 & 4987.550 & 000 & 6.81000 & 56.81000 & 30.16000 & 3987.759 & 84.34 & 15.2 & \\
\hline 1983 & 5089.810 & 00 & & 00 & 32.4 & 3820.800 & 77.0 & 15. & \\
\hline 1984 & 5216.960 & 52.30000 & 7.33000 & 57.33000 & 34.41000 & 3871.800 & 77.29000 & 15. & \\
\hline 1985 & 5304.360 & .55000 & 6.93000 & 56.93000 & 37.19000 & 3180.600 & 70.23600 & 15.30000 & 33 \\
\hline 1986 & 5077.960 & 49.39000 & 6.24000 & 56.24000 & 36.73000 & 2632.700 & 67.4 & 15.40000 & 71 \\
\hline 1987 & 5412.830 & 48.46000 & 6.47000 & 56.47000 & 37.63000 & 2214.200 & 70.6 & 15.60000 & 109 \\
\hline 1988 & 5386.600 & 3.68000 & 5.84000 & 55.84000 & 40.62000 & 2073.300 & 83.6 & 15.80000 & \\
\hline 1989 & 5508 & .23000 & 8.32000 & 58.32000 & 40.71000 & 2321.060 & 0 & 0 & 54 \\
\hline 1990 & 70 & 00 & 00 & 00 & 41. & 760 & 0 & 0 & 60 \\
\hline 1991 & 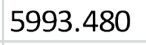 & 0 & 00 & 000 & 41. & 2687.250 & 500 & 15. & 51 \\
\hline 1992 & .732 & 00 & 00 & 61.76000 & 44.10000 & 3184.200 & 9900 & 0 & 91 \\
\hline 1993 & 6346.290 & 7.48000 & 58.86000 & 58.86000 & 45.27000 & 3305.100 & 1100 & 0 & \\
\hline 1994 & 6412.500 & 47.30 & 00 & 59.2 & 00 & 3338 & 00 & 00 & 37 \\
\hline 1995 & 6535 & U & 0 & 0 & 0 & 3112.800 & 90.1 & 15.6 & 14 \\
\hline 1996 & טוב.ד. & 40.91000 & 8.98000 & 58.98000 & 55.00000 & 3181.100 & 85.72000 & 15.70000 & 40.7319 \\
\hline 1997 & 1050.240 & 40.0 & 0.27000 & 60.27000 & 56.40000 & 3453.750 & 80.50000 & 10.50 & 70 \\
\hline 1998 & 7064.110 & 46.47000 & 60.30000 & 60.30000 & 57.68000 & 3653.900 & 79.98000 & 15.90000 & 100.4 \\
\hline 1999 & 118 & 40.150 & 0 & 6 & 5 & 9 & 0 & 00 & 82 \\
\hline 2000 & 1511.512 & 45.86000 & 0 & 6 & 60 & 4136.783 & 00 & 00 & 49 \\
\hline 2001 & 1051.852 & 45.36000 & 60.34000 & 60.34000 & 64.61000 & 4481.060 & 89.55000 & 15.10000 & 167.3138 \\
\hline 2002 & //85.321 & 45.01000 & 0.50000 & 60.50000 & 66.00000 & 4403.600 & 85.34000 & 15.30000 & 173.8270 \\
\hline 2003 & 7857.368 & 46.33000 & 62.35000 & 62.35000 & 67.38000 & 4262.700 & 82.39000 & 14.50000 & 80.3175 \\
\hline 2004 & 8010.1 & 46.27000 & 0 & 62.00000 & 68.38000 & 4306.049 & 00 & 00 & 298 \\
\hline 2005 & 8268.000 & 5.72000 & 62.55000 & 62.55000 & 68.83000 & 4424.040 & 90.25000 & 12.90000 & 191.4611 \\
\hline 2006 & 8573.100 & 5.40000 & 63.11000 & 63.11000 & 69.54000 & 4840.100 & 93.94000 & 12.50000 & 197.7520 \\
\hline 2007 & 8764.300 & 45.11000 & 63.63000 & 63.63000 & 70.39000 & 5147.000 & 104.0800 & 12.40000 & 204.2436 \\
\hline 2008 & 8925.500 & 4.90000 & 64.12000 & 64.12000 & 70.40000 & 5370.200 & 115.4000 & 12.40000 & 211.0000 \\
\hline 2009 & 9479.000 & 4.72000 & 4.50000 & 64.50000 & 68.83000 & 5736.096 & 94.37000 & 13.30000 & 220.0000 \\
\hline 2010 & 9717.500 & 4.51000 & 4.76000 & 64.76000 & 68.63000 & 6084.093 & 105.7500 & 13.00000 & 233.0000 \\
\hline 2011 & 9960.730 & 4.48000 & 5.08000 & 65.08000 & 70.23000 & 5512.797 & 105.8000 & 18.30000 & 246.3060 \\
\hline 2012 & 10210.05 & 44.47000 & 65.38000 & 65.38000 & 70.04000 & 4995.145 & 107.4800 & 17.60000 & 259.4790 \\
\hline 2013 & 10465.30 & 44.45000 & 65.67000 & 65.67000 & 69.85000 & 5052.837 & 103.0000 & 15.90000 & 388.4400 \\
\hline 2014 & 10726.93 & 44.42000 & 65.94000 & 65.94000 & 69.66000 & 4837.323 & 100.9200 & 15.10000 & 388.4400 \\
\hline
\end{tabular}




\section{PROMENE U STAROSNOJ STRUKTURI POPULACIJE I RADNA PRODUKTIVNOST: PRIMER TUNISA}

\section{Rezime:}

Oslanjajući se na makroekonomsku perspektivu, ovaj rad analizira uticaj starosne dobi populacije na produktivnost u poslu. $\mathrm{U}$ vezi sa tim, posmatrani su efekti nivoa učešća radne snage kroz tri starosne grupe - pripadnici mlađe populacije (15-29 godina), oni koji su dosegli punu zrelost (30-49 godina), starija populacija (50-64 godina). Nivo učešća radne snage - a po osnovu godina, posmatran je na način da se porede radno aktivni pripadnici iste starosne dobi. Koristeći podatke iz Tunisa, koji se odnose na vremenski okvir 1965-2014. godine, metod kointegracije je potvrdio dugoročni odnos sa procesom progresivnog prilagođavanja, na putu ka uspostavljanju ravnoteže. Za razliku od ishoda do kojih dovodi konvencionalni pristup, profil produktivnosti zasnovan na parametru starosne dobi, nije dobio obrnuti U-oblik. Radna produktivnost smanjivala se kada su u pitanju mladi radnici, rasla za one u zrelom dobu, te nastavila da raste - kada su u pitanju pripadnici starije populacije. U skladu sa tim, starenje populacije nije uticalo na učinak u okvirima tržišta rada u Tunisu. Otuda, kako bi se pospešila produktivnost, ali i unapredio ekonomski rast zemlje, preporučljivo je odlaganje penzionisanja populacije nakon šezdesete godine.

\section{Ključne reči:}

promene u starosnoj strukturi populacije, nivo učešća radne snage, radna produktivnost, model korigovanja greške, Tunis. 